\title{
Portfolio turnover and performance of equity investment funds in Brazil ${ }^{\star}$
}

\author{
Sabrina Espinele da Silva ${ }^{1}$ \\ (D) https://orcid.org/0000-0001-9451-144X \\ Email: sabrinaespinele@ufmg.br
}

\author{
Carolina Magda da Silva Roma ${ }^{2}$ \\ (D) https://orcid.org/0000-0003-1156-7558 \\ Email: carolina.magda.adm@gmail.com
}

Robert Aldo Iquiapaza ${ }^{3}$

(D) https://orcid.org/0000-0003-1657-2823

Email: rbali@ufmg.br

\begin{abstract}
1 Universidade Federal de Minas Gerais, Faculdade de Ciências Econômicas, Departamento de Administração, Belo Horizonte, MG, Brazil
2 Universidade Federal do Rio Grande, Instituto de Ciências Econômicas, Administrativas e Contábeis, Rio Grande, RS, Brazil

3 Universidade Federal de Minas Gerais, Faculdade de Ciências Econômicas, Centro de Pós-Graduação e Pesquisas em Administração, Belo

Horizonte, MG, Brazil
\end{abstract}

Received on 01.24.2019 - Desk acceptance on 02.18.2019 - $3^{\text {rd }}$ version approved on 07.22.2019 - Ahead of print on 12.09.2019

Associate Editor: Fernanda Finotti Cordeiro Perobelli

\begin{abstract}
The purpose of this paper was to analyze the relationships between the portfolio turnover and performance of equity investment funds in Brazil. There are few published studies on the subject, but the previously identified Brazilian studies that have examined making changes to portfolios have been limited to very restricted data samples and have only worked with an ordinary least squares (OLS) model without taking into account the indications of international studies and economic theory itself of the possible endogeneity of turnover, which would make OLS estimation inadequate. The expressive growth of the fund industry in the Brazilian market shows the relevance of the object of research. Two portfolio turnover metrics were analyzed: one based on changes in the monetary values of the assets and another based on changing the weights of the assets in the portfolio. The estimations were performed for fixed effects panel data and then for a two-stage least squares model, using instrumental variables. The funds that make up the sample are those classified as "free shares" in the period from January of 2012 to January of 2018. The results showed that there is a positive relationship between the portfolio turnover and performance of the equity investment funds, showing that managers have been able to take advantage of moments of mispricing in the market and that they carry out more trades in search of higher returns. This research extends the results in the literature as it shows that there is a positive relationship between the turnover and performance of equity investment funds that is independent of the way turnover or performance are measured, which has shown inconclusive results in previous studies. Furthermore, it presents evidence for a more representative and current sample in an emerging market.
\end{abstract}

Keywords: portfolio turnover, performance, investment funds.

Correspondence address

Sabrina Espinele da Silva

Universidade Federal de Minas Gerais, Faculdade de Ciências Econômicas, Departamento de Administração

Avenida Antônio Carlos, 6627, Prédio FACE - CEP 31270-901

Pampulha - Belo Horizonte - MG - Brazil

\footnotetext{
* The authors are grateful to the Fundação de Amparo à Pesquisa do Estado de Minas Gerais (Research Support Foundation of the State of Minas Gerais - Fapemig) for its financial support in carrying out this research.
} 


\section{INTRODUCTION}

Investment funds represent a collective investment modality, one of whose advantages is specialized management. In addition, they provide investors with the possibility of investing in various markets that individuals would find hard to access, thus facilitating diversification (Borges \& Martelanc, 2015; Fonseca, Bressan, Iquiapaza \& Guerra, 2007; Klapper, Sulla \& Vittas, 2004; Milani \& Ceretta, 2013; Varga \& Wengert, 2011).

Depending on the asset class, funds can be fixed income, equity, multimarket, or currency [Comissão de Valores Mobiliários (Brazilian Securities and Exchange Commission - CVM), 2014]. Here we look at equity investment funds, whose main risk factor is variations in the price of the stocks that compose their portfolios, as well as the obligation to invest at least $67 \%$ of their net equity in shares traded on the stock exchange (CVM, 2014). The equities that will compose their portfolios and their suitable rebalancing should be decided by a professional specialized in this task: the fund manager.

It is the manager's responsibility to allocate assets in the fund's portfolio such that it can achieve good performance. Performance is one of the critical aspects taken into account by investors when choosing a fund to invest in (Ferreira, Keswani, Miguel \& Ramos, 2013). This stage is relevant and can be considered as a feedback and control procedure that is able to make the process more effective. The aim is to make periodic comparisons of the risk and return incurred by a manager in an active management strategy with a benchmark (Oliveira \& Sousa, 2015).

According to Varga (2001), access to the best models and information for processing available information is what makes a manager able to outperform the market. Milan and Eid (2015) note that the manager of an equity fund should be constantly altering the assets that make up the portfolio, in an attempt to achieve better returns than the market average. In this context, Pástor, Stambaugh, and Taylor (2017) argue that fund managers trade more when they perceive profit-making opportunities. This renovation (alteration) of the assets in a portfolio represents its level of turnover.

One of the potential problems of high levels of investment fund portfolio turnover is associated with the transaction costs involved in frequent trading. However, Wermers (2000) argues that despite the greater transaction costs and expenses incurred by funds with a high turnover ratio, these are also the ones that hold equities with significantly higher average returns compared to funds with low turnover ratios. Vidal, Vidal-García, Lean, and Uddin (2015) corroborate this idea. However, other studies indicate a negative association between portfolio turnover levels and fund performance (Ang, Chen \& Lin, 1998; Champagne, Karoui \& Patel, 2018; Milan \& Eid, 2014). Consequently, choosing an investment fund that offers high returns with an acceptable risk limit is a complicated task (Ramasamy \& Yeung, 2003).

Petajisto (2013) notes that investors should pay attention to active management measures when searching for funds that are more skillful in choosing stocks. However, as the ultimate aim of investors is to invest in a fund that is able to deliver good performance, it is interesting to observe whether there are relationships between a fund's level of activity in terms of portfolio alterations and its performance.

Thus, the aim of this research is to analyze the relationships between the portfolio turnover and performance of equity investment funds in Brazil. This study aims to fill the gap observed in the literature on investment funds in the domestic market, since although there are many studies in the literature that discuss the performance of equity investment funds, related or not with characteristics such as size, age, administration fees, and others (Carhart, 1997; Chen, Hong, Huang \& Kubik, 2004; Mansor, Bhatti \& Ariff, 2015; Paz, Iquiapaza \& Bressan, 2017; Vidal et al., 2015), few papers analyze variations in the portfolio composition of these funds (turnover) and their impacts on performance.

In this context, the study by Milan and Eid (2014) comes closest to the proposal presented here. These authors analyzed the relationship between the turnover of funds' portfolios and their performance, but the sample was limited to only 47 equity funds.

This study, however, stands out from previous ones in various aspects: (i) it analyzes a larger sample of funds in a more recent period; (ii) it concentrates on those funds in which the manager has greater discretion to make alterations in the portfolio (free funds); (iii) it uses a new turnover measure based on alterations in the weights of the assets in the portfolios, recently proposed by Champagne et al. (2018); and (iv) it explores the question of endogeneity of turnover described by the literature and not yet explored by previous studies in Brazil. Thus, this study aims to contribute to enriching the literature on the performance of investment funds in Brazil, by showing that it is important to not only pay attention to 
the characteristics of the funds but also to the alterations made to their portfolios when choosing those that are able to achieve the best performance for their shareholders.

One of the main contributions consists of finding the existence of a positive and significant relationship between the portfolio turnover and performance of equity investment funds in Brazil. The robustness of this relationship was verified using more robust econometric models and different metrics for estimating portfolio turnover, as well as for measuring fund performance, thus making it possible to obtain more reliable results.

The article is structured in five sections. The first presents the contextualization and objectives of the research. The second discusses the main studies that guided this one. The third describes the methodological procedures adopted. The fourth presents and analyzes the results of the research. The fifth formulates the concluding remarks.

\section{THEORETICAL FRAMEWORK}

\subsection{Portfolio Turnover and Fund Performance}

Active portfolio management aims to provide investors with better returns than a particular market index (benchmark). To achieve such higher returns, a fund needs to assume different positions, whether through stock selection or through market timing (Chen, Gao, Zhang \& Zhu, 2017; Cremers \& Petajisto, 2009; Petajisto, 2013). Thus, active fund managers constantly alter their portfolio composition, buying and selling assets in the search for better returns (Milan \& Eid, 2014, 2015). These alterations to the portfolio define its level of turnover.

The research carried out, especially outside Brazil, has found various results from analyzing the relationship between turnover and performance (Table 1). In the studies that indicate a positive relationship between the volume of trades and subsequent performance of a fund (Cremers \& Petajisto, 2009; Pástor et al., 2017), this result is attributed to manager characteristics, such as experience and capacity to determine the best times to buy and sell an asset. They will trade more when they perceive more profit-making opportunities, and so a higher level of portfolio turnover may indicate better performance (Milan \& Eid, 2014; Pástor et al., 2017).

Pástor et al. (2017) explored the idea that fund managers trade more when they perceive good profitmaking opportunities. If the ability to find and exploit these opportunities exists, a greater number of trades will be associated with gaining high returns. The results of the aforementioned study showed that there is a positive relationship for equity mutual funds in the United States.

For Chevalier and Ellison (1999), a high portfolio turnover ratio can indicate that a lot of research is being carried out, enabling managers to select the best assets for making alterations in their portfolios. Consequently, turnover may be a way of indicating managerial effort (Golec, 1996).
Along these same lines, despite the higher transaction costs and expenses incurred by funds with a high turnover ratio, the evidence shows that these funds are also the ones that hold stocks with significantly higher average returns compared with funds with a low turnover ratio (Wermers, 2000) and they are able to outperform their benchmark (Cremers \& Petajisto, 2009). Accordingly, Vidal et al. (2015) argue that funds with a high turnover are also the ones that have the highest expected return.

Cremers and Petajisto (2009) add that in funds from the highest active share quintile, there has been significant performance persistence (measured by the benchmarkadjusted return) among equity funds in the United States. The authors proposed a measure (active share) to determine active management based on the positions assumed in stocks in the fund's portfolio that differ from the benchmark index portfolio. Thus, there would be a positive relationship between an increase in the fund's portfolio turnover and its subsequent performance.

However, the relationship between turnover and performance may not be significant. This evidence is found in the studies by Ippolito and Turner (1987) and Golec (1996), who analyzed the stock turnover and performance of funds in the United States.

However, when investors buy shares in funds, they are paying for the quality of the information that the managers have, in the expectation that they carry out trades to increase the fund's expected return, net of transaction costs. Thus, expenses and turnover would not have an impact on performance (Carhart, 1997). When analyzing fund portfolio revisions, Shukla (2004) found that, on average, these do not generate excess return net of transaction costs, even for holding periods of up to six months.

In contrast, there are also studies that indicate a negative relationship between the level of turnover and performance of funds. For example, Champagne 
et al. (2018) examined the idea of a measure capable of capturing active management using turnover based on portfolio rebalancing activities, that is, changes in the weights of the assets within a portfolio, called "modified turnover". The authors argued that if the managers have good information, they will probably trade more in an attempt to achieve good returns, which would indicate a supposed positive relationship between turnover and performance. In contrast, the managers may be trading more frequently based on irrelevant information or without any justification. In this case, the relationship between turnover and performance would be weak or negative.

Using a sample of equity funds from the United States, the results of the paper by Champagne et al. (2018) showed a negative relationship between the modified turnover and the future performance of the funds. The authors clarify that managers who frequently alter their portfolios may not be the most skillful, as very frequent trades in fact destroy value for investors.

In the Brazilian market, Milan and Eid (2014) concluded that the negative relationship between turnover and performance may be an indication that it is hard to obtain better returns than those of a market portfolio based on active management, which would be consistent with the market efficiency hypothesis proposed by Fama (1970). In fact, the results of the study by Nerasti and Lucinda (2016), who examined performance persistence in investment funds in Brazil, point to the existence of semi-strong efficiency in the Brazilian market, indicating the non-existence of differentiated information or the superior ability of portfolio managers.

\section{Table 1}

Main studies on the fund turnover vs. performance relationship

\begin{tabular}{|c|c|c|c|}
\hline Study & Market & Period & Result \\
\hline $\begin{array}{l}\text { Ippolito and Turner (1987), } \\
\text { pension funds }\end{array}$ & United States & 1977-1982 & $\begin{array}{l}\text { Negative relationship between the stock turnover and } \\
\text { performance of funds, but not verified in the mutual fund } \\
\text { industry. }\end{array}$ \\
\hline $\begin{array}{l}\text { Golec (1996), } \\
\text { growth, growth and income, } \\
\text { small stocks, and others }\end{array}$ & United States & 1988-1990 & $\begin{array}{l}\text { Demonstrated that there is not a significant relationship } \\
\text { between turnover and performance in equity investment } \\
\text { funds. }\end{array}$ \\
\hline $\begin{array}{l}\text { Wermers (2000), } \\
\text { equity funds }\end{array}$ & United States & $1975-1994$ & $\begin{array}{l}\text { Funds with a high turnover ratio also hold stocks with } \\
\text { significantly higher average returns compared with funds } \\
\text { with a low turnover ratio. }\end{array}$ \\
\hline $\begin{array}{l}\text { Cremers and Petajisto (2009), } \\
\text { equity funds }\end{array}$ & United States & $1980-2003$ & $\begin{array}{l}\text { They argue that in funds from the highest active } \\
\text { share quintile there has been significant performance } \\
\text { persistence (measured by the benchmark-adjusted return) } \\
\text { of equity funds. }\end{array}$ \\
\hline $\begin{array}{l}\text { Milan and Eid (2014), } \\
\text { equity funds }\end{array}$ & Brazil & $2007-2011$ & $\begin{array}{l}\text { Negative relationship between a high turnover of assets in } \\
\text { the fund's portfolio and its performance. }\end{array}$ \\
\hline $\begin{array}{l}\text { Vidal et al. (2015), } \\
\text { equity funds }\end{array}$ & United States & $1962-2012$ & $\begin{array}{l}\text { Funds with a high turnover also have the highest expected } \\
\text { return. }\end{array}$ \\
\hline $\begin{array}{l}\text { Pástor et al. (2017), } \\
\text { equity funds }\end{array}$ & United States & $1979-2011$ & Turnover positively predicts benchmark-adjusted return. \\
\hline $\begin{array}{l}\text { Champagne et al. (2018), } \\
\text { equity funds }\end{array}$ & United States & $1991-2012$ & $\begin{array}{l}\text { Negative relationship between the modified turnover and } \\
\text { future performance of funds. }\end{array}$ \\
\hline
\end{tabular}

Source: Elaborated by the authors.

\subsection{Other Determinant Characteristics of Investment Fund Performance}

Besides the relationships between the alterations made to a fund's portfolio and its performance, the academic literature on funds has demonstrated that some of their characteristic aspects have an impact on their performance. Aspects such as age, administration fees, performance fees, and size of the fund are taken as determinants of performance.
The studies by Milani and Ceretta (2013) and Alda, Andreu, and Sarto (2017) have shown increases in the performance of funds with increases in their age. One explanation for this phenomenon is found in Golec (1996), who noted that a fund's age measures its survival in the market, as well as the loyalty of its investors and its prestige. However, a negative relationship between a fund's age and its performance is indicated in the Brazilian studies by Berggrun, Mongrut, Umaña, and Varga (2014) and Mendonça, Campani, and Leal (2017). 
With regards to fees, where the main service provided by a fund is portfolio management, those that funds charge the investor should reflect their risk-adjusted performance (Gil-Bazo \& Ruiz-Verdú, 2009). However, Grinblatt and Titman (1989) note that although some managers are able to generate abnormal returns (above the market average), these are diluted by the effects of fees (administration and performance) and transactions costs.

In Brazil, Dalmácio, Nossa, and Zanquetto (2008) indicate the non-existence of a correlation between administration fees and fund performance. In contrast with these authors, Castro and Minardi (2009) and Silva, Roma, and Iquiapaza (2018) note that fund shareholders should pay attention to the value of administration fees, given that these can have a negative impact on fund performance.
With relation to the size of the fund, Chen et al. (2004) argue that a fund's size corrodes its performance. According to the authors, questions related to liquidity can force managers of large funds to invest in bad ideas or to assume greater positions in stocks than is ideal, thus damaging their performance, while managers of small funds would only invest money in their best ideas. Pollet and Wilson (2008) indicate that fund managers are reluctant to diversify their portfolios as their funds grow. In this context, Ferreira et al. (2013) found evidence that there are important differences between the determinants of fund performance in the United States and the rest of the world. Their results showed that there is a negative size effect in the United States, but a positive size effect for other countries, as well as a negative age effect for funds from outside that country.

\section{METHODOLOGY}

\subsection{Sample Definition and Data Collection}

The population of this study covers equity investment funds that engage in active management. These are divided into seven subcategories: value/growth, dividends, sustainability/governance, small caps, active index, sectoral, and free. It can be observed that the funds from the "free" subcategory manage more than $60 \%$ of the net equity invested in active equity funds, according to data from the Brazilian Association of Financial and Capital Market Entities (Anbima, 2018), and can therefore be considered representative of these. In addition, these funds' managers are expected to have more freedom to change their portfolios, since they are not geared towards specific sectors, characteristics, or indices.

Thus, the final sample is made up of the funds classified in the "free", non-exclusive subcategory, according to the new Anbima (2015) fund classification, given their greater representativeness in the period from January of 2012 to January of 2018, which covers six years of analyses. After restricting the funds to those with a minimum of 48 months of returns data, the final sample was made up of 130 free shares funds [including quota investment funds (FICs) and stock investment funds (FIAs)]. Note that the sample minimizes the survival bias as it includes funds starting and closing during the period; only 23 funds were active during the whole sampling period, varying between 25 in 2012 to 118 in 2017 and 109 in 2018.

As described below, monthly information was collected on the equity investment funds and stock market quotations to calculate the modified turnover, fund performance, and risk factors of the proposed models. The sources were the SI-ANBIMA system and the ComDinheiro and Economatica ${ }^{\circledR}$ platforms.

The monthly composition of the portfolios of all the funds in the sample was obtained from the ComDinheiro platform, covering December of 2011 to January of 2018 , so that the monthly turnover of the funds could be obtained from January of 2012 onwards (the data on the portfolios prior to December of 2011 were not available on the ComDinheiro platform, which therefore constitutes a limitation of the study).

The value of a share in the funds, administration fee, net equity, and start and end dates of the funds were obtained from the SI-ANBIMA system. To calculate fund performance, the data were collected from January of 2007 to January of 2018, according to the methodology proposed for the alpha calculation, which uses the 60 months (five years) of prior returns for the estimation, as will be explained below. Note that the value of the administration fees, when unavailable on the SI-ANBIMA system, was consulted directly in the fund's regulations, which can be found using the fund's CNPJ number on the CVM website.

Building the risk factors of the Carhart (1997) model required information on the companies listed on the stock exchange (B3 - Brasil, Bolsa, Balcão). The data on monthly closing price, equity value, and market value of the stocks, as well as data on the return on the interbank deposit certificate (CDI) (proxy for the return on the risk- 
free asset) and on the Bovespa Index (Ibovespa) (proxy for market return), were obtained from Economatica ${ }^{\circledR}$. How the factors were constructed is explained in the next subsection.

\subsection{Risk Factors of the Stocks}

The excess market return in relation to the risk-free asset $\left(R_{m}-r_{f}\right)$ covers the first risk factor in the capital asset pricing model (CAPM) and the Carhart model. The smallminus-big (SMB), high-minus-low (HML), and moment (MOM) risk factors were constructed in a similar way to that proposed by Fama and French (1993) and Carhart (1997). The constructed portfolios were formed at the end of June of each year $t$ and held during the period from July of year $t$ to June of year $t+1$, and the inputs needed for this include: the market value of the stocks, the bookto-market ratio (ratio between the firm's net equity and its market value), and the short-term cumulative return. Data on all the stocks traded on the B3 were used, excluding those belonging to firms with negative net equity and those that form part of the financial sector, given that the latter present specific accounting characteristics.

Specifically, at the end of June of each year $t$, the assets were classified into two subgroups, based on the median of their market value, to form the small (low market value - S) and big (high market value - B) portfolios. Next, the 30 and 70 percentiles of the book-to-market variable were used as a reference to divide the assets into portfolios with high, medium, and low market-tobook values, called high $(\mathrm{H})$, neutral $(\mathrm{N})$, and low $(\mathrm{L})$, respectively. This construction was carried out at the end of June of each year $t$ based on the relationship between the net equity and market value of the assets at the end of December of year $t-1$.

Thus, six portfolios were formed using their market capitalization as a weighting system, considering the intersection of the size and the book-to-market value of the assets variables, namely: $S H, S N, S L, B H, B N$, and $B L$. The SMB factor can then be obtained as the average return of the three small portfolios subtracted from the average return of the three big portfolios. The HML factor was built based on the difference between the average return of two portfolios formed of stocks with high market-tobook values and the average return of two portfolios with low book-to-market values.

To construct the MOM factor, at the end of June of each year $t$, first the assets were divided based on the median of their market value into two groups, small (S) and big (B). Then, based on the cumulative return from the last 11 months, the assets were divided into the 30 and 70 percentiles to form three portfolios: winner (W), neutral $(\mathrm{N})$, and loser $(\mathrm{L})$. Thus, six portfolios were formed using the market value of the assets as a weighting system, namely: $S W, S N, S L, B W, B N$, and $B L$. The MOM factor was obtained as the difference between the average return of the two portfolios with the highest returns (winners) and the average return of the two portfolios with the lowest returns (losers).

\subsection{Estimation and Econometric Procedures}

\subsubsection{Fund performance estimation}

\subsubsection{Calculation of net return and gross return of the funds}

Given that the administration fee is one of the explanatory variables of the proposed models, this study chose to use the gross returns from which the administration fee was not yet extracted, which is a similar procedure to that adopted by different authors, such as Castro and Minardi (2009), Paz et al. (2017), and Silva et al. (2018); however the results were also estimated for net returns. According to Edelen (1999, p. 445), "the relationship between discretionary trading and abnormal returns could be easily analyzed using gross returns in relation to net returns".

Thus, the net return of the funds was calculated based on the value of the disclosed fund shares (which are already net of administration fees). The form of calculation can be observed in equation 1 .

$$
\text { Net_Return }{ }_{i, t}=\frac{\text { Share_Value }_{i, t}-\text { Share_Value }_{i, t-1}}{\text { Share_Value }_{i, t-1}} 1
$$

The gross return calculation follows the procedures carried out by Castro and Minardi (2009), Paz et al. (2017), and Silva et al. (2018), and can be observed in equation 2 .

$$
\text { Gross_Return }_{i, t}=\text { Net_Return }{ }_{i, t}+\left((1+a d m . f e e)^{\left(\frac{1}{12}\right)}-1\right) \quad 2
$$

in which Net_Return ${ }_{i, t}$ is the net return of fund $i$ in month $t$, Gross_Return $n_{i, t}$ is the gross return of fund $i$ in month $t$, and $a d m . f e e$ is the annual administration fee corresponding to the year of month $t$.

In order to avoid the effect of possible outliers, the fund returns series was subjected to the winsorization process at $0.5 \% .0 .5 \%$ of the highest returns and $0.5 \%$ of the lowest returns were winsorized; a similar procedure was carried out by Yin (2016) and Malaquias and Maestri (2017). In addition, a boxplots analysis of the fund performance measures showed only one fund whose performance 
during the whole period differed substantially from the performance of the rest of the sample. Thus, we chose to exclude this fund from the sample.

\subsubsection{Estimation of the alpha and of the Sharpe ratio (SR) of the funds}

The performance of the funds was measured by the alpha (CAPM model and Carhart model) and by the generalized SR, according to equations 3,4 , and 5, respectively. Note that the Ibovespa was used as a proxy for the market return, while the CDI rate was used as a proxy for the risk-free rate. Oliveira and Sousa (2015) and Fernandes, Fonseca, and Iquiapaza (2018) used a similar approach.

The estimation of the regressions of the alphas was carried out in a similar way to that proposed by GilBazo and Ruiz-Verdú (2009). Thus, to obtain the alphas, a regression of all the funds with at least 48 months of returns data was carried out, regressing the excess return of the funds against the risk factors in a 60-month (five-year) moving window. The second stage consisted of obtaining the fund's alpha as the intercept of the aforementioned regression.

For the CAPM model:

$$
R_{i, t}-R F_{t}=\alpha_{i}+\beta_{i}\left(R M_{t}-R F_{t}\right)+\varepsilon_{i, t}
$$

$R_{i, t}-R F_{t}$ refers to the excess return of fund $i$ at time $t, \alpha_{i, t}$ represents the alpha of fund $i$ in month $t$, the abnormal return above the market average, $\beta$ represents the sensitivity of the fund's return to the risk premium of the market, $\left(R M_{t}-R F_{t}\right)$ represents the excess return of the market, and $\varepsilon_{i, t}$ is the error term of the model.

For the Carhart model:

$$
R_{i, t}-R F_{t}=\alpha_{i}+b_{i}\left(R M_{t}-R F_{t}\right)+s_{i} S M B_{t}+h_{i} H M L_{t}+p_{i} M O M_{t}+\varepsilon_{i, t}
$$

$S M B$ is the premium for the size factor in month $t, H M L$ is the premium for the book-to-market factor (book value/market value - BV/MV) in month $t, M O M$ is the premium for the moment factor in month $t$, and $\varepsilon_{i, t}$ is the error term of the model,

$$
S R_{c}=\frac{r_{c}-r_{f}}{\sigma_{c}}
$$

in which $r_{c}$ is the average return on the fund's portfolio, $r_{f}$ is the return on the risk-free asset, and $\sigma_{c}$ is the total risk of the fund's portfolio.

The SR was adjusted using the procedure proposed by Israelsen (2005). This author considers that for a negative risk-adjusted return, the SR becomes negative and its reliability and comparability decrease. In this case, among the funds with equal return, with equation 5 , those with the highest volatility would tend to have the best SR. Thus, it would be appropriate to transform the denominator of the SR equation. This procedure can be observed in equation 6 .

$$
\text { adjusted_SR }=\frac{r_{c}-r_{f}}{\frac{r_{c}-r_{f}}{\sigma_{c}-r_{f} \mid}}
$$

in which adjusted_SR is the SR adjusted using the procedure of Israelsen (2005) and $\left|r_{c}-r_{f}\right|$ is the module of the excess return on the asset. Thus, in cases of a negative premium, the SR continues to be negative, but those funds with a higher risk are penalized, resulting in a more consistent ordering.

\subsubsection{Estimation of the funds' portfolio turnover}

Following the studies by Carhart (1997) and Barber and Odean (2000), Gaspar, Massa, and Matos (2005) developed the churn rate (CR) metric, which is capable of indicating the level of turnover of assets in a portfolio. In Brazil, the model was used by Milan and Eid (2014; 2015). We chose to use this metric to calculate the funds' level of turnover, according to equation 7 .

$$
C R_{i, t}=\frac{\sum_{j}\left|N_{j, i, t} P_{j, t}-N_{j, i, t-1} P_{j, t-1}-N_{j, i, t-1} \Delta P_{j, t}\right|}{\sum_{j} \frac{N_{j, i, t} P_{j, t}+N_{j, i, t-1} P_{j, t-1}}{2}}
$$

in which $i$ represents the investment fund, $t$ is the month of publication of the composition of the fund, and $j$ is the company that issued the stock. Thus, $N_{j, i, t}$ represents the number of stocks in company $j$ that compose the portfolio of fund $i$ in month $t$ and $P_{j, t}$ represents the unit price of a stock in company $j$ for month $t$.

In addition, the level of turnover of the fund's portfolio was also calculated using a metric that varies between 1 (portfolio completely modified between $t-1$ and $t$ ) and 0 (portfolio did not undergo any alteration between $t$ and $t-1$ ), as according to equation 8 , following the procedure proposed by Champagne et al. (2018).

$$
\begin{gathered}
M T_{j, t}=\frac{1}{2} \sum_{i=1}^{N_{j}}\left|\omega_{i, t}^{\text {observed }}-\omega_{i, t}^{B H}\right| \\
\omega_{i, t}^{B H}=\omega_{i, t-1}^{\text {osserved }}\left(\frac{1+R_{i, t}}{1+R_{j, t}^{B H}}\right)
\end{gathered}
$$


in which $M T_{i, t}$ represents the modified turnover of fund $j$ at time $t, \omega_{i, t}^{\text {observed }}$ is the observed weight of stock $i$ for the $\mathrm{j}$-th funds at the end of month $t, \omega_{i, t}^{B H}$ is the weight of stock $i$ bought and held at the end of month $t, N_{j}$ is the total number of different stocks held both at the end of month $t-1$ and at the end of $t, R_{i, t}$ is the return on stock $i$ in month $t$, and $R_{j, t}^{B H}$ is the buy-and-hold (BH) portfolio return of fund $j$ in month $t$ and calculated according to equation 10 .

$$
R_{j, t}^{B H}=\sum_{i=1}^{N_{j}} \omega_{i, t-1}^{\text {observed }} R_{i, t}
$$

The weights of all the positions in stocks within the portfolio were added up, not including other asset classes. Consequently, the weights in the equations are adjusted by dividing them by the sum of the total weights. This obtains a sum of adjusted weights equal to 1 . In addition, the multiplication by $0.5(1 / 2)$ in equation 8 aims to restrict the modified turnover value to a scale between 0 and 1 .
Intuitively, the modified turnover (MT) measure can be interpreted according to Champagne et al. (2018) in the following way: passively managed funds that make few modifications in their portfolios between months $t-1$ and $t$ will have a MT value close to 0 ; in contrast, more actively managed funds that make a lot of changes in their portfolios from period $t-1$ to $t$ will have a MT measure close to 1 . Thus, this way of calculating turnover controls for alterations in the weights of the assets that result from relative price variations, effectively measuring alterations caused by the manager.

\subsubsection{Selection and operationalization of the independent and control variables}

With relation to the operationalization of the independent variables of the proposed model, Table 2 explains the form of calculation, as well as the expected sign, according to the empirical evidence from previous studies.

Table 2

Calculation of the explanatory and control variables

\begin{tabular}{|c|c|c|c|c|}
\hline Id & Variable & Operationalization & Sign & Reference \\
\hline 1 & MT & $\begin{array}{l}\text { Fund portfolio turnover according to that } \\
\text { specified in the preceding section }\end{array}$ & + & $\begin{array}{l}\text { Wermers (2000), } \\
\text { Vidal et al. (2015), } \\
\text { Pástor et al. (2017) }\end{array}$ \\
\hline 2 & FundAge & Control variable represented by the fund's age & + & $\begin{array}{c}\text { Golec (1996), } \\
\text { Milani and Ceretta (2013), } \\
\text { Alda et al. (2017) }\end{array}$ \\
\hline 3 & Fee & $\begin{array}{l}\text { Effective monthly administration fee charged } \\
\text { by the fund }\end{array}$ & - & $\begin{array}{l}\text { Grinblatt and Titman } \\
\text { (1989), Gil-Bazo and } \\
\text { Ruiz-Verdú (2009), Vidal } \\
\text { et al. (2015) }\end{array}$ \\
\hline 4 & $N E$ & $\begin{array}{l}\text { Control variable represented by the natural } \\
\text { logarithm of the fund's monthly net equity }\end{array}$ & + & $\begin{array}{c}\text { Chen et al. (2004), } \\
\text { Gottesman and Morey } \\
\text { (2006), Milani and Ceretta } \\
\text { (2013) }\end{array}$ \\
\hline
\end{tabular}

Note: The fourth column presents the expected sign according to the empirical evidence from previous studies.

Source: Elaborated by the authors.

\subsubsection{Econometric procedures}

The data were initially analyzed using the panel data regression technique. To decide the best model to use pooling, fixed effects, or random effects - the Hausman test (Greene, 2002) was carried out. The first regression run aimed to verify the relationships between portfolio turnover and fund performance; thus the model in equation 11 was estimated.

$$
P E R_{i, t}=\alpha_{i}+\beta_{1} M T_{i, t}+\beta_{2} \text { FundAge }_{i, t}+\beta_{3} F e_{i, t}+\beta_{4} N E_{i, t}+\varepsilon_{i, t}
$$


in which $M T_{i, t}$ represents the funds' turnover, referring to both measures used for calculating it, and performance refers to one of the three measures specified in the section "Fund performance estimation". FundAge refers to the fund's age, Fee to the administration fee, and $N E$ to the fund's net equity, and they are control variables.

\subsubsection{Instrumental variables}

Golec (1996), Chevalier and Ellison (1999), and Gottesman and Morey (2006) argue that a portfolio's turnover may have a simultaneity relationship with its performance. To illustrate, if all remains constant, a fund that presents poor performance will tend to present increases in turnover, given that the manager will have incentives to alter the portfolio's composition. Along the same lines, if performance is satisfactory, the turnover may be lower.
From this perspective, it is understood that the fund's turnover is an endogenous variable (Chevalier \& Ellison, 1999; Golec, 1996; Gottesman \& Morey, 2006). This means that, as an independent variable, turnover will probably have a correlation with the error term in the performance equation (Golec, 1996). However, one of the assumptions of the least squares model is that the independent variables and the error term are not correlated. Otherwise, the model produces biased and inconsistent estimators.

We thus chose the instrumental variables method, using the two-stage least squares model. The method is based on using a $z$ variable that has a high correlation with the endogenous variable, but not with the error (Heij, Boer, Philip, Kloek \& Dijl, 2005). As an instrument, the lagged turnover is used, as proposed by Chevalier and Ellison (1999).

\section{PRESENTATION AND ANALYSIS OF RESULTS}

\subsection{Descriptive Statistics}

\subsubsection{Descriptive statistics of fund performance}

Table 3 shows the descriptive statistics of the performance of the free shares funds in the period from January of 2012 to January of 2018. The alpha estimated using Carhart (1997) and CAPM are presented, as well as the SR corrected by the Israelsen (2005) procedure, the fund's excess return, which represents the fund's return subtracted from the risk-free rate (CDI), and the descriptive statistics of the risk factors.

Table 3

Descriptive statistics of the performance of the free shares funds

\begin{tabular}{lccccccccccc}
\hline & Obs. (n) & Minimum & Maximum & $\begin{array}{c}\mathbf{1}^{\text {st }} \\
\text { quartile }\end{array}$ & $\begin{array}{c}3^{\text {rd }} \\
\text { quartile }\end{array}$ & Mean & $\begin{array}{c}\text { Standard } \\
\text { deviation }\end{array}$ & $\begin{array}{c}\text { Asymmetry } \\
\text { Kurtosis }\end{array} \begin{array}{c}\text { Jarque- } \\
\text { Bera }\end{array}$ \\
\hline FFC4_Alpha & 4,250 & -0.016 & 0.024 & 0.000 & 0.007 & 0.004 & 0.005 & -0.428 & 0.939 & 0.000 \\
\hline CAPM_Alpha & 4,250 & -0.022 & 0.026 & 0.000 & 0.008 & 0.003 & 0.006 & -0.711 & 1.614 & 0.000 \\
\hline Sharpe Ratio & 4,250 & -0.005 & 0.573 & 0.000 & 0.083 & 0.053 & 0.088 & 2.065 & 4.403 & 0.000 \\
\hline ExC. Ret. & 4,250 & -0.219 & 0.193 & -0.028 & 0.039 & 0.005 & 0.056 & -0.016 & 1.348 & 0.000 \\
\hline RM-RF & 206 & -0.260 & 0.158 & -0.044 & 0.049 & 0.000 & 0.065 & -0.244 & 0.695 & 0.000 \\
\hline SMB & 206 & -0.110 & 0.191 & -0.023 & 0.029 & 0.003 & 0.045 & 0.601 & 1.417 & 0.000 \\
\hline HML & 206 & -0.195 & 0.163 & -0.043 & 0.015 & -0.014 & 0.053 & -0.086 & 0.880 & 0.024 \\
\hline MOM & 206 & -0.214 & 0.130 & -0.024 & 0.042 & 0.008 & 0.054 & -0.531 & 1.168 & 0.000 \\
\hline
\end{tabular}

Note: At the $5 \%$ significance level, $29.83 \%$ of the funds in the sample, in the period analyzed, obtained positive and significant alphas and $0.56 \%$ had negative and significant alphas.

Source: Elaborated by the authors.

It is found that, on average, the funds obtained positive alphas and achieved a higher return than the risk-free rate, presenting a positive average monthly excess return. In Table 3, it is observed that, on average, the funds obtained positive performance measured by the alpha in both models. In the FFC4 model, the monthly mean was $0.35 \%$, with a standard deviation of $0.53 \%$, while in the CAPM model the mean was $0.33 \%$, with a standard deviation of $0.62 \%$. This indicates that, on average, the funds managed to achieve higher returns than the benchmark in the period. In addition, the maximum monthly performance achieved by the funds in the period was $2.42 \%$ and the minimum monthly performance was $-1.62 \%$. 
Furthermore, the funds obtained a mean monthly risk/return ratio, measured by the SR, of $5.28 \%$, with a monthly standard deviation of $8.82 \%$. The $\mathrm{p}$-value of the Jarque-Bera test showed that the performance data are not normally distributed. The asymmetry and kurtosis values also confirm this affirmation.

\subsubsection{Descriptive statistics of the portfolio turnover and other characteristics of the funds}

Table 4 presents the descriptive statistics of the portfolio turnover measures. In addition, it presents the descriptive statistics of the funds' characteristics. Note that all the variables are measured in monthly terms, with the exception of the fund's age, which is measured in years.
The funds present in the sample have a minimum age of five years in operation. The oldest fund has been operating for 32 years and the mean age of the funds present in the sample is approximately nine years. All this information can be observed in Table 4 .

Table 4 reveals that the managers made a maximum change of $87 \%$ of the weights of the stocks within their portfolios, with a minimum change of $0 \%$; that is, there were months in which some funds kept their positions in stocks unaltered. The mean monthly change in terms of weight of the stocks within the portfolio is $10 \%$, while the mean monthly change in terms of value invested is $21 \%$. It is also observed that the portfolio turnover values do not follow a normal distribution, according to the Jarque-Bera test.

Table 4

Descriptive statistics of the portfolio turnover and other characteristics of the free shares funds

\begin{tabular}{lccccccccccc}
\hline Variables & Obs. $(\mathbf{n})$ & Unit & Min. & Max. & $\begin{array}{c}\mathbf{1}^{\text {st }} \\
\text { quartile }\end{array}$ & $\begin{array}{c}\mathbf{3}^{\text {rd }} \\
\text { quartile }\end{array}$ & Mean & $\begin{array}{c}\text { Standard } \\
\text { deviation }\end{array}$ & $\begin{array}{c}\text { Asymmetry } \\
\text { Kurtosis }\end{array}$ & $\begin{array}{c}\text { Jarque- } \\
\text { Bera }\end{array}$ \\
\hline Churn rate & 4,250 & & 0.000 & 2.000 & 0.070 & 0.290 & 0.210 & 0.210 & 2.620 & 11.790 & 0.000 \\
\hline Turnover & 4,250 & & 0.000 & 0.870 & 0.040 & 0.140 & 0.100 & 0.080 & 1.760 & 5.960 & 0.000 \\
\hline NE & 4,250 & Log & 14.000 & 22.100 & 16.600 & 19.270 & 17.980 & 1.730 & 0.150 & -0.720 & 0.000 \\
\hline Fee & 4,250 & $\begin{array}{c}\text { Monthly } \\
\%\end{array}$ & 0.000 & 0.006 & 0.000 & 0.002 & 0.001 & 0.001 & 1.200 & 1.720 & 0.000 \\
\hline FundAge & 4,250 & Years & 5.000 & 32.000 & 6.000 & 10.000 & 9.300 & 4.630 & 2.050 & 4.740 & 0.000 \\
\hline
\end{tabular}

Note: Churn rate refers to the turnover calculated using the Gaspar et al. (2005) metric; Turnover refers to the turnover calculated using the Champagne et al. (2018) metric.

Source: Elaborated by the authors.

The minimum net equity of the funds present in the sample is approximately $\$ 1$ million, with a maximum equity of more than $\$ 3$ billion. The mean net equity is a little higher than $\$ 64$ million. These values can be obtained by applying the exponential function to the values presented in logarithm in Table 4. These values also not follow a normal distribution, as the $\mathrm{p}$-value from the Jarque-Bera test indicates.

With relation to administration fees, Table 4 shows that in the sample there are funds that do not change them, given that the minimum fee value is $0 \%$, and the funds with the highest fees charge $0.57 \%$ a month. This represents a fee of approximately $7 \%$ a year. The mean fee charged by the funds is $0.12 \%$ a month, which represents an annual fee of approximately $1.45 \%$. The fee data also do not present a normal distribution, as the Jarque-Bera test indicates.

\subsection{Turnover versus Performance Relationship}

In the search to answer the proposed research question, the first estimation carried out sought to verify the relationship between the portfolio turnover and performance of the funds, which is the model in equation 11. In Table 5, it is possible to observe the results of the regressions, using fixed effects panel data for the turnover versus performance relationship.

The model presented in Table 5 indicates contradictory results, given that it presents a possible negative relationship between turnover and performance, this measured by the alpha, when the turnover measure is based on the values of the assets in the portfolio, and an apparently positive relationship when the turnover measure is based on the weight of the assets. But these relationships were not significant at the $5 \%$ level. In relation to performance measured by the SR, in both cases the model presented a negative relationship. However, due to the possible endogeneity of turnover in relation to the alpha as already indicated by the literature (Chevalier \& Ellison, 1999; Golec, 1996; Gottesman \& Morey, 2006), we chose to use the instrumental variables method, which is believed to be capable of providing a more consistent estimator of the parameters of interest. The results of this model, which can be observed in Table 6, were estimated using twostage least squares, with lagged turnover as an instrument. 
Table 5

Panel data regressions for the turnover versus performance relationship (free shares funds) in the period from January of 2012 to January of 2018

Panel A

\begin{tabular}{|c|c|c|c|c|c|c|}
\hline \multicolumn{7}{|c|}{ Gross performance } \\
\hline \multirow{2}{*}{$\begin{array}{l}\text { Fixed effects } \\
\text { Churn rate }\end{array}$} & \multicolumn{2}{|c|}{ FFC4 } & \multicolumn{2}{|c|}{ CAPM } & \multicolumn{2}{|c|}{ SR } \\
\hline & -0.00019 & & -0.00041 & . & -0.01243 & $* *$ \\
\hline $\mathrm{NE}$ & 0.00176 & $* * *$ & 0.00244 & $* * *$ & 0.02324 & $* * *$ \\
\hline Fee & -0.86494 & $*$ & 0.24401 & & -11.68116 & \\
\hline Fund's age & -0.00090 & $* * *$ & -0.00084 & $* * *$ & -0.00966 & $* * *$ \\
\hline $\mathrm{R}^{2}$ & 0.27261 & & 0.28103 & & 0.11280 & \\
\hline Adjusted $\mathrm{R}^{2}$ & 0.24873 & & 0.25743 & & 0.08368 & \\
\hline F-statistic & 376.74800 & $* * *$ & 392.93300 & $* * *$ & 127.80800 & *** \\
\hline Breusch-Godfrey & 342.25000 & $* * *$ & 414.68000 & $* * *$ & 505.54000 & $* * *$ \\
\hline Hausman test & 89.74200 & $* * *$ & 49.71300 & $* * *$ & 37.69500 & $* * *$ \\
\hline
\end{tabular}

\begin{tabular}{|c|c|c|c|c|c|c|}
\hline \multicolumn{7}{|c|}{ Gross performance } \\
\hline Fixed effects & \multicolumn{2}{|c|}{ FFC4_Alpha } & \multicolumn{2}{|c|}{ CAPM_Alpha } & \multicolumn{2}{|c|}{ SR } \\
\hline Turnover & 0.00103 & . & 0.00004 & & -0.02270 & . \\
\hline $\mathrm{NE}$ & 0.00176 & $* * *$ & 0.00244 & $* * *$ & 0.02331 & $* * *$ \\
\hline Fee & -0.93353 & $*$ & 0.11481 & & -13.62544 & . \\
\hline Fund's age & -0.00087 & $* * *$ & -0.00081 & $* * *$ & -0.00930 & $* * *$ \\
\hline $\mathrm{R}^{2}$ & 0.26705 & & 0.27565 & & 0.11048 & \\
\hline Adjusted $\mathrm{R}^{2}$ & 0.24313 & & 0.25201 & & 0.08145 & \\
\hline F-statistic & 368.44800 & $* * *$ & 384.82200 & $* * *$ & 125.60100 & $* * *$ \\
\hline Breusch-Godfrey & 342.25000 & $* * *$ & 414.68000 & $* * *$ & 512.03000 & $* * *$ \\
\hline Hausman test & 79.77400 & $* * *$ & 15.27000 & $* *$ & 40.02300 & $* * *$ \\
\hline \multicolumn{7}{|c|}{ Panel C } \\
\hline \multicolumn{7}{|c|}{ Net performance } \\
\hline Fixed effects & \multicolumn{2}{|c|}{ FFC4 } & \multicolumn{2}{|c|}{ CAPM } & \multicolumn{2}{|c|}{ SR } \\
\hline Churn rate & -0.00018 & & -0.00042 & . & -0.01201 & $* *$ \\
\hline $\mathrm{NE}$ & 0.00177 & $* * *$ & 0.00243 & $* * *$ & 0.01627 & $* * *$ \\
\hline Fee & -1.05217 & $* *$ & 0.03640 & & -10.48056 & \\
\hline Fund's age & -0.00092 & $* * *$ & -0.00085 & $* * *$ & -0.00946 & $* * *$ \\
\hline $\mathrm{R}^{2}$ & 0.28039 & & 0.28419 & & 0.10097 & \\
\hline Adjusted $\mathrm{R}^{2}$ & 0.25676 & & 0.26070 & & 0.07145 & \\
\hline F-statistic & 391.67800 & $* * *$ & 399.11000 & $* * *$ & 112.89500 & $* * *$ \\
\hline Breusch-Godfrey & 324.75000 & $* * *$ & 403.90000 & $* * *$ & 499.05000 & $* * *$ \\
\hline Hausman test & 73.22900 & $* * *$ & 36.13300 & $* * *$ & 45.63000 & $* * *$ \\
\hline \multicolumn{7}{|c|}{ Panel D } \\
\hline \multicolumn{7}{|c|}{ Net performance } \\
\hline Fixed effects & \multicolumn{2}{|c|}{ FFC4_Alpha } & \multicolumn{2}{|c|}{ CAPM_Alpha } & \multicolumn{2}{|c|}{ SR } \\
\hline Turnover & 0.00100 & & -0.00002 & & -0.02129 & . \\
\hline NE & 0.00176 & $* * *$ & 0.00243 & $* * *$ & 0.01638 & $* * *$ \\
\hline Fee & -1.11852 & $* *$ & -0.09214 & & -12.37551 & . \\
\hline Fund's age & -0.00089 & $* * *$ & -0.00082 & $* * *$ & -0.00912 & $* * *$ \\
\hline $\mathrm{R}^{2}$ & 0.27499 & & 0.27893 & & 0.09860 & \\
\hline
\end{tabular}


Table 5

Cont.

Panel D

\begin{tabular}{|c|c|c|c|c|c|c|}
\hline \multicolumn{7}{|c|}{ Panel D } \\
\hline \multicolumn{7}{|c|}{ Net performance } \\
\hline Fixed effects & \multicolumn{2}{|c|}{ FFC4_Alpha } & \multicolumn{2}{|c|}{ CAPM_Alpha } & \multicolumn{2}{|c|}{ SR } \\
\hline Adjusted $\mathrm{R}^{2}$ & 0.25133 & & 0.25540 & & 0.06918 & \\
\hline F-statistic & 383.56500 & $* * *$ & 391.17400 & $* * *$ & 110.61000 & $* * *$ \\
\hline Breusch-Godfrey & 337.66000 & $* * *$ & 413.74000 & $* * *$ & 502.61000 & $* * *$ \\
\hline Hausman test & 40.86800 & $* * *$ & 140.86000 & $* * *$ & 45.77300 & $* * *$ \\
\hline
\end{tabular}

CAPM_Alpha $=$ alpha calculated using the capital asset pricing model (CAPM); FFC4_Alpha = alpha calculated by the regression that uses the four risk factors of Carhart; $S R=$ indicates the generalized Sharpe ratio corrected using the procedure of Israelsen (2005); NE = net equity.

$*, * *, * *=$ statistically significant at 5,1 , and $0.1 \%$, respectively.

Source: Elaborated by the authors.

Table 6 enables it to be deduced that there is a positive and statistically significant relationship between portfolio turnover and performance measured by the alpha of the Brazilian funds. Thus, greater levels of changes to a portfolio are associated with achieving better performance. These results support the empirical evidence of the studies by Vidal et al. (2015) and Pástor et al. (2017). Note that the results were estimated using both gross and net returns and they did not change, showing that managers who make more changes to their portfolios are capable of delivering better performance for fund shareholders even after the payment of administration fees.

In addition, it is found that the net equity and administration fees of the funds also have a positive relationship with performance, while the fund's age presented a negative relationship. Thus, the empirical evidence indicates that larger and younger funds are capable of delivering higher performance measured by the alpha. These results support the studies by Mendonça et al. (2017), who argue that more recent funds tend to achieve better performance, and are in line with the empirical evidence of the studies by Castro and Minardi (2009) and Milani and Ceretta (2013), who found positive relationships between fund size and performance.

However, it should be mentioned that the $\mathrm{Wu}$ Hausman test enabled the rejection of the null hypothesis only for the models in which performance was measured by the alpha, showing that the instrumental variables model produces more efficient estimates for these cases. For the SR, the model enabled the rejection of the null hypothesis only at $10 \%$, providing indications that the OLS model is possibly more consistent. However, in both estimations, the results for performance measured by the SR did not present statistical robustness, given that they presented statistical significance for one turnover measure, while they did not present significance for the alternative measure. These results are consistent with those of the study by Milan and Eid (2014), who did not find statistical significance for the turnover/performance relationship for cases in which performance is measured by the SR.

Table 6

Estimation using instrumental variables for the turnover versus performance relationship (free shares funds) in the period from January of 2012 to January of 2018

\begin{tabular}{|c|c|c|c|c|c|c|}
\hline \multicolumn{7}{|c|}{ Panel A } \\
\hline \multicolumn{7}{|c|}{ Gross performance } \\
\hline Churn rate & \multicolumn{2}{|c|}{ FFC4_Alpha } & \multicolumn{2}{|c|}{ CAPM_Alpha } & \multicolumn{2}{|c|}{ SR } \\
\hline Intercept & -0.02524 & $* * *$ & -0.03298 & $* * *$ & -0.37302 & $* * *$ \\
\hline Churn rate & 0.00368 & $*$ & 0.00586 & $* * *$ & 0.00508 & \\
\hline Fee & 1.31694 & $* * *$ & 1.45872 & $* * *$ & 12.48466 & $* * *$ \\
\hline $\mathrm{NE}$ & 0.00162 & $* * *$ & 0.00198 & $* * *$ & 0.02418 & $* * *$ \\
\hline Fund's age & -0.00028 & $* * *$ & -0.00024 & $* * *$ & -0.00260 & $* * *$ \\
\hline $\mathrm{R}^{2}$ & 0.26750 & & 0.27080 & & 0.20370 & \\
\hline Adjusted $\mathrm{R}^{2}$ & 0.26670 & & 0.27010 & & 0.20290 & \\
\hline Weak instrument & 131.73900 & $* * *$ & 131.73900 & $* * *$ & 131.73900 & $* * *$ \\
\hline Wu-Hausman test & 5.04600 & $*$ & 9.10700 & $* *$ & 0.30800 & \\
\hline
\end{tabular}


Table 6

Cont.

Panel B

\begin{tabular}{|c|c|c|c|c|c|c|}
\hline \multicolumn{7}{|c|}{ Gross performance } \\
\hline Turnover & \multicolumn{2}{|c|}{ FFC4_Alpha } & \multicolumn{2}{|c|}{ CAPM_Alpha } & \multicolumn{2}{|c|}{ SR } \\
\hline Intercept & -0.02545 & $* * *$ & -0.03339 & $* * *$ & -0.37709 & $* * *$ \\
\hline Turnover & 0.01054 & $* * *$ & 0.01778 & $* * *$ & 0.09642 & $*$ \\
\hline Fee & 1.34330 & $* * *$ & 1.49675 & $* * *$ & 12.29059 & $* * *$ \\
\hline NE & 0.00161 & $* * *$ & 0.00197 & $* * *$ & 0.02380 & $* * *$ \\
\hline Fund's age & -0.00028 & $* * *$ & -0.00023 & $* * *$ & -0.00234 & $* * *$ \\
\hline $\mathrm{R}^{2}$ & 0.26960 & & 0.26890 & & 0.19910 & \\
\hline Adjusted $R^{2}$ & 0.26890 & & 0.26820 & & 0.19830 & \\
\hline Weak instrument & 270.96000 & $* * *$ & 270.96000 & $* * *$ & 270.96000 & $* * *$ \\
\hline Wu-Hausman test & 6.49700 & $*$ & 17.13000 & $* * *$ & 3.39100 & . \\
\hline
\end{tabular}

\begin{tabular}{|c|c|c|c|c|c|c|}
\hline \multicolumn{7}{|c|}{ Net performance } \\
\hline \multirow{2}{*}{$\begin{array}{l}\text { Churn rate } \\
\text { Intercept }\end{array}$} & \multicolumn{2}{|c|}{ FFC4_Alpha } & \multicolumn{2}{|c|}{ CAPM_Alpha } & \multicolumn{2}{|c|}{ SR } \\
\hline & -0.02540 & $* * *$ & -0.03306 & $* * *$ & -0.30066 & $* * *$ \\
\hline Churn rate & 0.00374 & $* *$ & 0.00589 & $* * *$ & 0.01882 & \\
\hline Fee & 0.34512 & $* * *$ & 0.47926 & $* * *$ & 4.79372 & $* * *$ \\
\hline $\mathrm{NE}$ & 0.00162 & $* * *$ & 0.00198 & $* * *$ & 0.01966 & $* * *$ \\
\hline Fund's age & -0.00028 & $* * *$ & -0.00024 & $* * *$ & -0.00206 & $* * *$ \\
\hline $\mathrm{R}^{2}$ & 0.30820 & & 0.30000 & & 0.18350 & \\
\hline Adjusted $\mathrm{R}^{2}$ & 0.30750 & & 0.29930 & & 0.18260 & \\
\hline Weak instrument & 131.73900 & $* * *$ & 131.73900 & $* * *$ & 131.73900 & $* * *$ \\
\hline Wu-Hausman test & 5.13600 & $*$ & 5.13600 & $* *$ & 1.24500 & \\
\hline \multicolumn{7}{|c|}{ Panel D } \\
\hline \multicolumn{7}{|c|}{ Net performance } \\
\hline Turnover & \multicolumn{2}{|c|}{ FFC4_Alpha } & \multicolumn{2}{|c|}{ CAPM_Alpha } & \multicolumn{2}{|c|}{ SR } \\
\hline Intercept & -0.02562 & $* * *$ & -0.03347 & $* * *$ & -0.30490 & $* * *$ \\
\hline Turnover & 0.01067 & $* * *$ & 0.01779 & $* * *$ & 0.12316 & $* * *$ \\
\hline Fee & 0.37262 & $* * *$ & 0.51783 & $* * *$ & 4.76062 & $* * *$ \\
\hline $\mathrm{NE}$ & 0.00162 & $* * *$ & 0.00197 & $* * *$ & 0.01930 & $* * *$ \\
\hline Fund's age & -0.00028 & $* * *$ & -0.00023 & $* * *$ & -0.00181 & $* * *$ \\
\hline $\mathrm{R}^{2}$ & 0.31030 & & 0.29830 & & 0.17830 & \\
\hline Adjusted $\mathrm{R}^{2}$ & 0.30960 & & 0.29760 & & 0.17740 & \\
\hline Weak instrument & 270.96000 & $* * *$ & 270.96000 & $* * *$ & 270.96000 & $* * *$ \\
\hline Wu-Hausman test & 6.73300 & $* *$ & 17.36000 & $* * *$ & 5.84700 & $*$ \\
\hline
\end{tabular}

CAPM_Alpha = alpha calculated using the capital asset pricing model (CAPM); FFC4_Alpha = alpha calculated by the regression that uses the four risk factors of Carhart; $S R=$ indicates the generalized Sharpe ratio corrected using the procedure of Israelsen (2005); NE = net equity.

*,**,** = statistically significant at 5, 1, and $0.1 \%$, respectively.

Source: Elaborated by the authors. 
According to Golec (1996), a higher level of portfolio turnover may be indicative of managerial effort. Chevalier and Ellison (1999) consider that a high level of turnover may indicate that a lot of research is being carried out, which could enable the selection of the best market assets. Wermers (2000) also argues that those funds with high turnover ratios are also the ones that have presented higher average returns.

These results indicate that those managers who engage in more active management are capable of delivering better performance. According to Pástor et al. (2017), assuming that managers have training and experience to determine the best times for buying and selling an asset, they will trade more when they perceive more profitmaking opportunities.
With relation to fund characteristics, it was found that those with a higher net equity value and younger ones are able to deliver better performance. With regards to administration fees, the positive relationship found diverges from the results found by other authors (GilBazo \& Ruiz-Verdú, 2009; Vidal et al., 2015). However, Christoffersen and Musto (2002) argue that the constitution of funds' fees is based on the elasticity of the demand for shares in them, so that those that have investors with less elastic demand would charge higher fees. In addition, other authors argue that the value of the fees may be related to investor sentiment $(\mathrm{Hu}$, Chao \& Lim, 2016), with funds probably charging higher fees in periods of low sentiment.

\section{CONCLUDING REMARKS}

Fund performance is known to be one of the key variables in an investor's decision-making process regarding whether to invest in a particular fund or not. Thus, many studies have focused on finding the determinant variables of such performance. However, most of these studies have focused on fund characteristics, such as size, administration fees, and age, while little attention has been paid to the composition of and alterations made to the portfolios of these funds.

Therefore, this study aimed to analyze the relationships between the portfolio turnover, which refers to the alterations made in the assets that compose a portfolio in a particular month, and performance of equity investment funds in the period from January of 2012 to January of 2018.

The results of the estimations indicated the existence of a positive relationship between portfolio turnover and fund performance measured by the alpha. It is found that managers are able to identify and take advantage of market mispricing moments and that they carry out more trades in search of higher returns when they perceive more profit-making opportunities, as highlighted by Pástor et al. (2017). In addition, this result provides indications of the absence of strong efficiency in the Brazilian market. Thus, the actions of professional investors may be desirable and investing in funds could be advantageous.

Complementarily, a positive effect was found of the administration fees and net equity of the funds on their achieving better gross performance. As Milani and Ceretta (2013) note, larger funds may benefit from economies of scale, which could explain the positive relationship between size and performance. Finally, it was found that younger funds achieve better performance, as argued by other authors (Ferreira et al., 2013; Mendonça et al., 2017; Silva et al., 2018).

Note that this study is not free from limitations, since the conclusions mentioned refer to the sample studied and to the established time limit. The sample was built by convenience and was limited by the availability of data. The difficult access to the database on the composition of the funds' portfolios configured one of the limitations, as the ComDinheiro platform presents information for the funds' portfolio compositions from December of 2011 onwards and, therefore, the period analyzed was limited to the one in which data were available.

We suggest that future studies seek to explore a longer time period, so it may be possible to investigate the influence of bear and bull market periods. In addition, the study could be extended to other fund categories, such as fixed income or even multimarket ones. 


\section{REFERENCES}

Alda, M., Andreu, L., \& Sarto, J. L. (2017). Learning about individual managers' performance in UK pension funds: The importance of specialization. North American Journal of Economics and Finance, 42, 654-667. https://doi.org/10.1016/j. najef.2017.09.006

Ang, J. S., Chen, C. R., \& Lin, J. W. (1998). Mutual fund managers' efforts and performance. The Journal of Investing, 7(4), 68-75. https://doi.org/10.1016/S0022-3913(12)00134-5

Associação Brasileira das Entidades dos Mercados Financeiro e de Capitais (Brazilian Association of Financial and Capital Market Entities). (2015). Cartilha da nova classificação de fundos. Rio de Janeiro, RJ: Anbima.

Associação Brasileira das Entidades dos Mercados Financeiro e de Capitais (Brazilian Association of Financial and Capital Market Entities). (2018). Fundos de investimento Consolidado histórico de fundos de investimento, janeiro de 2018. Rio de Janeiro, RJ: Anbima.

Barber, B. M., \& Odean, T. (2000). Trading is hazardous to your wealth: The common stock investment performance of individual investors. Journal of Finance, 55(2), 773-806. https://doi.org/10.1111/0022-1082.00226

Berggrun, L., Mongrut, S., Umaña, B., \& Varga, G. (2014). Persistence in equity fund performance in Brazil. Emerging Markets Finance and Trade, 50(2), 16-33. https://doi. org/10.2753/REE1540-496X500202

Borges, E. C., \& Martelanc, R. (2015). Sorte ou habilidade: Uma avaliação dos fundos de investimento no Brasil. Revista de Administração, 50(2), 196-207. https://doi.org/10.5700/ rausp1194

Carhart, M. M. (1997). On persistence in mutual fund performance. The Journal of Finance, 52(1), 57-82. https://doi. org/10.1111/j.1540-6261.1997.tb03808.x

Castro, B. R., \& Minardi, A. M. A. F. (2009). Comparação do desempenho dos fundos de ações ativos e passivos. Revista Brasileira de Financas, 7(2), 1-13.

Champagne, C., Karoui, A., \& Patel, S. (2018). Portfolio turnover activity and mutual fund performance. Managerial Finance, 44(3), 326-356. https://doi.org/10.1108/MF-01-2017-0003

Chen, J., Hong, H., Huang, M., \& Kubik, J. D. (2004). Does fund size erode mutual fund performance? The role of liquidity and organization. American Economic Review, 94(5), 1276-1302. https://doi.org/10.1257/0002828043052277

Chen, R., Gao, Z., Zhang, X., \& Zhu, M. (2017). Mutual fund managers' prior work experience and their investment skills. Financial Management, 47(1), 1-22. https://doi.org/10.1111/ fima. 12180

Chevalier, J., \& Ellison, G. (1999). Are some mutual fund managers better than others? Cross-sectional patterns in behavior and performance. The Journal of Finance, 54(3), 875899. https://doi.org/10.1111/0022-1082.00130

Christoffersen, S. E. K., \& Musto, D. K. (2002). Demand curves and the pricing of money management. The Review of Financial Studies, 15(5), 1499-1524. https://doi.org/10.1093/ $\mathrm{rfs} / 15.5 .1499$
Comissão de Valores Mobiliários (Brazilian Securities and Exchange Commission). CVM Instruction 555, of December 17 of 2014. Describes the constitution, management, workings, and disclosure of information of investment funds. Retrieved from http://www.cvm.gov.br/legislacao/instrucoes/inst555.html

Cremers, K. J. M., \& Petajisto, A. (2009). How active is your fund manager a new measure that predicts performance. Review of Financial Studies, 22(9), 3329-3365. https://doi.org/10.1093/ rfs/hhp057

Dalmácio, F. Z., Nossa, V., \& Zanquetto, H., Filho. (2008). Avaliação da relação entre a performance e a taxa de administração dos fundos de ações ativos brasileiros. Revista de Educação e Pesquisa Em Contabilidade (REPeC), 1(3), 1-20. https://doi.org/10.17524/repec.v1i3.13

Edelen, R. M. (1999). Investor fows and the assessed performance of open-end mutual funds. Journal of Financial Economics, 53(3), 439-466.

Fama, E. F. (1970). Efficient capital markets : A review of theory and empirical work. The Journal of Finance, 25(2), 383-417. https://doi.org/10.1111/j.1540-6261.1970.tb00518.x

Fama, E. F., \& French, K. R. (1993). Common risk factors in the returns on stocks and bonds. Journal of Financial Economics, 33(1), 3-56. https://doi.org/10.1016/0304-405X(93)90023-5

Fernandes, A. R. de J., Fonseca, S. E., \& Iquiapaza, R. A. (2018). Modelos de mensuração de desempenho e sua influência na captação líquida de fundos de investimento. Revista Contabilidade \& Finanças, 29(78)435-451. https://doi. org/10.1590/1808-057x201805330

Ferreira, M. A., Keswani, A., Miguel, A. F., \& Ramos, S. B. (2013). The determinants of mutual fund performance: A crosscountry study. Review of Finance, 17(2), 483-525. https://doi. org/10.1093/rof/rfs013

Fonseca, N. F., Bressan, A. A., Iquiapaza, R. A., \& Guerra, J. P. (2007). Análise do desempenho recente de fundos de investimento no Brasil. Contabilidade Vista \& Revista, 18(1), 95-116. https://doi.org/10.2139/ssrn.1156606

Gaspar, J. M., Massa, M., \& Matos, P. (2005). Shareholder investment horizons and the market for corporate control. Journal of Financial Economics, 76(1), 135-165. https://doi. org/10.1016/j.jfineco.2004.10.002

Gil-Bazo, J., \& Ruiz-Verdú, P. (2009). The relation between price and performance in the mutual fund industry. Journal of Finance, 64(5), 2153-2183. https://doi.org/10.1111/j.15406261.2009.01497.x

Golec, J. H. (1996). The effects of mutual fund managers' characteristics on their portfolio performance, risk and fees. Financial Services Review, 5(2), 133-147. https://doi. org/10.1016/S1057-0810(96)90006-2

Gottesman, A. A., \& Morey, M. R. (2006). Manager education and mutual fund performance. Journal of Empirical Finance, 13(2), 145-182. https://doi.org/10.1016/j.jempfin.2005.10.001

Greene, W. H. (2002). Econometric analysis (5 ${ }^{\text {th }}$ ed.). Upper Saddle River, NJ: Pearson Education. https://doi.org/10.1198/ jasa.2002.s458 
Grinblatt, M., \& Titman, S. (1989). Mutual fund performance An analysis of quarterly portfolio holdings. The Journal of Business, 62(3), 393-416.

Heij, C., Boer, P. de, Philip, H. F., Kloek, T., \& Dijl, H. K. van. (2005). Econometric Methods with applications in business and economics. Decision Support systems. New York, NY: Oxford University Press. https://doi.org/978-0-19-926801-6

Hu, M., Chao, C., \& Lim, J. H. (2016). Another explanation of the mutual fund fee puzzle. International Review of Economics and Finance, 42(C), 134-152. https://doi.org/10.1016/j. iref.2015.11.002

Ippolito, R. A., Turner, J. A. (1987). Turnover, fees and pension plan performance. Financial Analysts Journal, 43(6), 16-26. https://doi.org/10.2469/faj.v43.n6.16

Israelsen, C. L. (2005). A refinement to the Sharpe ratio and information ratio. Journal of Asset Management, 5(6), 423427. https://doi.org/10.1057/palgrave.jam.2240158

Klapper, L., Sulla, V., \& Vittas, D. (2004). The development of mutual funds around the world. Emerging Markets Review, 5(1), 1-38. https://doi.org/10.1016/j.ememar.2003.12.001

Malaquias, R., \& Maestri, C. (2017). Effects of manager characteristics on portfolio composition of multimarket funds. Revista Universo Contábil, 13(2), 89-108. https://doi. org/10.4270/ruc.2017210

Mansor, F., Bhatti, M. I., \& Ariff, M. (2015). New evidence on the impact of fees on mutual fund performance of two types of funds. Journal of International Financial Markets, Institutions and Money, 35, 102-115. https://doi.org/10.1016/j. intfin.2014.12.009

Mendonça, J. A., Jr., Campani, C. H., \& Leal, R. P. C. (2017). A escolha de fundos de ações e o investidor individual [Special edition]. RAC - Revista de Administração Contemporânea, 21, 41-62. https://doi.org/10.1590/1982-7849rac2017160037

Milan, P. L. A. B., \& Eid, W., Jr. (2014). Elevada rotatividade de carteiras e o desempenho dos fundos de investimento em ações. Revista Brasileira de Finanças, 12(4), 469-497.

Milan, P. L. A. B., \& Eid, W., Jr. (2015). Determinantes da rotatividade das carteiras dos fundos de investimento em ações. Brazilian Business Review, 12(5), 1-16. https://doi. org/10.15728/bbr.2015.12.5.1

Milani, B., \& Ceretta, P. S. (2013). Efeito tamanho nos fundos de investimento brasileiros. Revista de Administração da UFSM, 6(1), 119-138. https://doi.org/10.5902/198346593607

Nerasti, J. N., \& Lucinda, C. R. C. R. C. R. (2016). Persistência de desempenho em fundos de ações no Brasil. Brazilian Review of Finance, 14(2), 269-297.
Oliveira, B. G. de, Filho, \& Sousa, A. F. de. (2015). Fundos de investimento em ações no Brasil: Métricas para avaliação de desempenho. Revista de Gestão, 22(1), 61-76. https://doi. org/10.5700/rege551

Pástor, L., Stambaugh, R. F., \& Taylor, L. A. (2017). Do funds make more when they trade more? Journal of Finance, 72(4), 1483-1528. https://doi.org/10.1111/jofi.12509

Paz, R. L., Iquiapaza, R. A., \& Bressan, A. A. (2017). Influence of investor' monitoring on equity mutual funds' performance. Gestão, Finanças e Contabilidade, 7(2), 79. https://doi. org/10.18028/2238-5320/ rgfc.v7n2p79-101

Petajisto, A. (2013). Active share and mutual fund performance. Financial Analysts Journal, 69(4), 73-93. https://doi. org/10.2469/faj.v69.n4.7

Pollet, J. M., \& Wilson, M. (2008). How does size affect mutual fund behavior? The Journal of Finance, LXIII(6), 2941-2969.

Ramasamy, B., \& Yeung, M. C. H. (2003). Evaluating mutual funds in an emerging market: factors that matter to financial advisors. International Journal of Bank Marketing, 21(3), 122 136. https://doi.org/10.1108/02652320310469502

Shukla, R. (2004). The value of active portfolio management. Journal of Economics and Business, 56(4), 331-346. https://doi. org/10.1016/j.jeconbus.2004.01.002

Silva, S. E., Roma, C. M. da S., \& Iquiapaza, R. A. (2018). A taxa de administração sinaliza o desempenho dos fundos de investimento em ações no Brasil? Revista de Educação e Pesquisa Em Contabilidade (REPeC), 12(3), 286-302. https:// doi.org/10.17524/repec.v12i3.1717

Varga, G. (2001). Índice de Sharpe e outros indicadores de performance aplicados a fundos de ações brasileiros. Revista de Administração Contemporânea, 5(2), 215-245. https://doi. org/10.1590/S1415-65552001000300011

Varga, G., \& Wengert, M. (2011). A indústria de fundos de investimentos no Brasil. Revista de Economia e Administração, 10(1), 66-109. https://doi.org/10.11132/rea.2010.361

Vidal, M., Vidal-García, J., Lean, H. H., \& Uddin, G. S. (2015). The relation between fees and return predictability in the mutual fund industry. Economic Modelling, 47(C) 260-270. https://doi.org/10.1016/j.econmod.2015.02.036

Wermers, R. (2000). Mutual fund performance: An empirical decomposition into stock picking talent, style, transactions costs, and expenses. The Journal of Finance, 55(4), 1655-1695. https://doi.org/10.1111/0022-1082.00263

Yin, C. (2016). The optimal size of hedge funds: Conflict. The Journal of Finance, LXXI(4), 1857-1894. https://doi. org/10.1111/jofi.12413 